\title{
Strategic, unaffordability and dual-trigger default in the Irish mortgage market ${ }^{2}$
}

\author{
Gregory Connor, Thomas Flavin* \\ Department of Economics, Finance and Accounting, National University of Ireland Maynooth, Maynooth, Co. Kildare, Ireland
}

\section{A R T I C L E I N F O}

\section{Article history:}

Received 3 December 2013

Revised 24 December 2014

Accepted 24 December 2014

Available online 5 January 2015

\section{JEL codes:}

R30

G21

\section{Keywords:}

Strategic default

Irish mortgage market

Negative equity

\begin{abstract}
A B S T R A C T
A mortgage holder whose property is worth less than the repayment value of the mortgage may decide to strategically default, i.e., renege on the cash flow liability of the mortgage loan and surrender the property to the mortgage issuer. In other circumstances a mortgage holder may default due to personal income decline which makes payment infeasible (unaffordability default) or for a combination of strategic and affordability causes (dual-trigger default). This paper utilizes a database of troubled Irish mortgages to model the default decisions of Irish mortgage holders. We include both affordabilityrelated and strategic-related explanatory variables. We find that both types of explanatory variables play a role in the explosive growth in Irish mortgage default after the Irish banking crisis and temporary legal prohibition of property repossession. We find that a dual-trigger model of default best fits the Irish data. Given the unusual features of the Irish market, our findings both complement and strengthen existing empirical findings from other national mortgage markets.
\end{abstract}

(C) 2014 Elsevier Inc. All rights reserved.

\section{Introduction}

During the period 2002-2012, Ireland experienced a spectacular credit bubble and subsequent financial collapse. This credit bubble and bust was roughly coincident with the global credit-liquidity crisis, but was notably extreme both in the exuberance of the upswing and sever-

\footnotetext{
We wish to acknowledge support from the Science Foundation of Ireland under grant 08/SRC/FM1389. We would like to thank Permanent TSB for provision of the data used in this study; Liam Delaney, Conall MacCoille, Donal O'Neill, and participants at the National University of Ireland Maynooth economics seminar and the Dublin Economics Workshop for helpful comments; and Anita Suurlaht for excellent research assistance.

* Corresponding author.

E-mail addresses: gregory.connor@nuim.ie (G. Connor), thomas.flavin@nuim.ie (T. Flavin).

1 See Connor et al. (2012) for a comparison of the US and Irish credit crises.
}

ity of the crash. ${ }^{1}$ Following the collapse of the Irish credit bubble, Irish residential property prices fell sharply and mortgage arrears grew explosively. From the peak in the second quarter of 2007, residential property prices fell $50.3 \%$ to the trough in the second quarter of 2012, subsequently recovering $1.2 \%$ by the second quarter of 2013 . The number of home mortgages in default (greater than 90 days of accumulated arrears) grew by a truly spectacular $272.6 \%$, from 26,271 in quarter three of 2009 to 97,874 in quarter two of 2013; as of quarter two 2013, 12.7\% of home loan mortgages were in default. Aggregate data on buy-tolet defaults is only available for a short period so the growth path is not known, but $20.4 \%$ of buy-to-let mortgages were in default as of quarter two of 2013.

In addition to the large credit bubble and bust, the Irish mortgage market had unusual institutional features during this period. Most existing Irish residential mortgages are contractually written to be full recourse and with unhindered security against the property. However, following 
the Irish financial collapse there were a number of legislative and regulatory changes that altered the de facto nature of mortgage claims. In July 2009, near the beginning of the crisis, the Irish government passed a new law which contained a legal error (called a "lacuna") which rendered virtually all mortgage property repossessions impossible until the lacuna was fixed. This outcome was not the stated intention of the law, but the legal lacuna was politically convenient at the time, and was not corrected via amending legislation until May 2013. Also in response to the crisis, in February 2010 the Irish Central Bank implemented regulations severely restricting the ability of banks to contact or harass delinquent borrowers; these restrictions were subsequently relaxed in July 2013. For most of our sample, Irish residential mortgages were, in practice, limited-recourse contracts with strictly limited security against the property asset, and potentially very high transactions costs for the mortgage lender in eventually exercising the security claim.

The unusual economic and institutional environment in Ireland over this recent period makes an examination of property mortgage default behavior of considerable interest. Ireland during this period provides a natural experiment regarding the effects on mortgage holder behavior of a very sharp fall in property prices and a concurrent block on property repossessions. We use a data set of distressed Irish mortgages to model Irish mortgage default behavior during this period. We attempt to distinguish between the three causal channels for mortgage default: strategic default, unaffordability default, and dual-trigger default.

Strategic default can be understood using options theory. The owner of a residential property subject to a nonrecourse mortgage who is willing to renege on his loan essentially holds a put option against the market value of the property. If the market price of the property falls sufficiently, the owner can surrender the property to the mortgage lender and in exchange receive full offset of his cash flow liability from the mortgage loan. In options terminology, the homeowner has a long-term American put option on a dividendpaying asset (the implicit rental yield of the property serves as the dividend flow) with exercise price equal to the cashequivalent value of the mortgage liability. The moneyness of the put option is one minus the reciprocal of the loan-tovalue ratio of the mortgage; the put option has positive moneyness if and only if the mortgage holder is in negative equity (loan-to-value ratio greater than one). A similar, but diluted, put optionality holds for recourse mortgages, since there are legal and practical limits to a mortgage lender's recourse claim against the owner's future income, for example, relief from this claim through personal bankruptcy. In a perfect-markets theory with no transactions costs nor any other market imperfections, a mortgage holder will only default on a full-recourse mortgage if there is both an inability to pay and negative equity (otherwise the property can be immediately sold to clear the debt). With a no-recourse loan in this perfect-markets world, the mortgage holder will default whenever there is negative equity (inability to pay does not impact the decision).

Strategic default often involves reputational costs and social/ethical considerations for the homeowner, since in doing so the homeowner violates the terms of an agreed contract for personal gain. In many cases, the mortgage lender will continue to receive (more valuable) required mortgage payments even when options theory predicts that it will be forced to accept surrender of the property.

Unlike strategic default, unaffordability default is caused by a lack of personal income to pay the mortgage; by definition, unaffordability default is not caused by the options value of default. Dual-trigger default refers to a mixed-caused case in which the mortgage holder has stressed mortgage affordability but also is influenced by the positive options-exercise value of default due to negative equity in the property.

In most situations, both the homeowner and mortgage lender incur substantial transactions costs from repossession. This two-sided transactions-cost feature of the put option leads to a bargaining game between the homeowner and mortgage lender, with the homeowner potentially able in some circumstances to gain mortgage payment concessions by threatening to surrender the asset but not doing so. The bargaining power of the mortgage borrower in default seeking repayment concessions increases with the moneyness of the put option. Stressed affordability can also impact upon the bargaining power of the mortgage holder, since the lender cannot easily distinguish between strained affordability and true unaffordability. This bargaining game aspect can explain dual-trigger default in which both the strategic (options-exercise) value of default and stressed affordability play an interactive role.

This paper empirically examines the causal variables explaining the behavior of Irish mortgage defaulters. We include both affordability-related and strategic-related explanatory variables. We rely on a large database of Irish mortgages provided to us by one of Ireland's largest mortgage lenders, Permanent TSB. The database covers all mortgages at Permanent TSB for which the holder has submitted a Standard Financial Statement (SFS), giving a sample of 28,377 mortgage accounts. Submitting an SFS is a required component of the Central Bank of Ireland's mandated mortgage arrears resolution process (MARP). The entry of a mortgage borrower into MARP is either at the initiation of the bank after one or more missed mortgage payments or, less commonly, by the mortgage borrower looking to engage with the bank for help with their mortgage payment difficulties. The sample is not representative of all mortgages; it consists only of mortgages which have been brought into MARP. The sample therefore has two different sources of sample selection. One, the sample does not include mortgages which have had no income stress or payment difficulty and so justifiably are not in MARP. Two, the sample does not include troubled mortgages which should be in MARP but where the mortgage borrower has refused to submit the required SFS. Our data consists of information from the SFS collated with information from the original loan application and some other loan-specific data items. Roughly half the mortgages in our sample are in default, defined as greater than 90 days worth of accumulated payment arrears, and half are performing loans. The dataset is a static, cross-sectional sample (September 2013) but includes some historical information for each mortgage as of that date.

Our main empirical task is to build a model explaining which of this observed subset of all mortgages, i.e. the 
subset of mortgages in MARP where the borrower has submitted an SFS, are in default, and which are not. We use a combination of analysis of variance, multivariable probit models and nonparametric and semiparametric kernelbased estimators. We find that both strategic and affordability variables play a role in explaining Irish mortgage default behavior. Whereas in US data, unaffordability is generally found to be more important than strategic behavior as a predictor of default, within our Irish sample the strategic motive appears to be equally or more important than unaffordability. The loan-to-value ratio, which measures the moneyness of the implicit put option, is the most powerful variable in generating differences in average default rates across portfolios of loans double-sorted by levels of explanatory variables. In a multivariate probit model of mortgage default, loan-to-value is again the most important explanatory variable, measured by marginal contribution to the probability of default. The strategic motive is particularly strong when combined with household income stress, supporting the dual trigger model of mortgage default.

Using nonparametric and semiparametric methods, we find some evidence for an options-type convexity in the functional link of loan-to-value to mortgage default probability. This convex relationship also conforms to findings in US-based research on the effect of loan-to-value on mortgage default rates.

Section 2 reviews the existing literature and critically examines the insights which existing research can provide regarding mortgage default behavior in Ireland. Section 3 describes our main econometric model of mortgage default. Section 4 empirically examines the default behavior of mortgages in our database. Section 5 summarizes the paper.

\section{Default behavior of mortgage borrowers}

There is a large literature modeling the default behavior of mortgage borrowers. The empirical component of this research is mostly based on US mortgage market data. We will briefly review some of the papers with particular relevance.

The original insight for modeling mortgage default as a put option is credited to Asay (1978). Deng et al. (2000) show empirically that a continuous-time, frictionless market, Black-Scholes-type theory of mortgage default as put option exercise provides useful empirical content, but is not sufficient as an empirical model. Unlike the exercise of a securities-market traded put option on a stock, defaulting on a mortgage has large fixed costs, and a potentially large impact on the future economic opportunities of the mortgage borrower, particularly through its impact on their personal credit rating and the availability of new mortgage finance to them. Deng et al. also note that mortgage default is not fully "rational" in the sense of cash-flow maximizing - there are moral/social/psychological aspects to the default decision. Most of the recent literature does not rely on the continuous-time, frictionless market assumptions of Black-Scholes type models.

Elmer and Seelig (1999) build a model of mortgage default which combines both the unaffordability motive and strategic motive as causes of default. Using US data aggregated at the state and regional level, they find that both causes play a role in mortgage default, but that the unaffordability motive is relatively stronger. The data used in the paper pre-dates the volatile US property price declines of the post-2007 period.

Using loan-level data, Tirupattur et al. (2010) conclude that defaults driven by negative equity, rather than ability to pay, are a significant phenomenon in US residential mortgages over their sample period. A borrower is defined as strategically in default (that is, exercising their put option) when their mortgage goes from current to 30-, 60- and then 90-days in arrears without any payment during this period or any subsequent payments, while the borrower continues to service non-mortgage loans. Strategic defaults increase over time in concert with the decline in US residential property prices and by the end of the sample (February 2010), they represent $12 \%$ of all defaulted mortgages. Wyman (2009) uses a similar approach and estimates that by the second quarter of $2009,19 \%$ of all defaults were strategic rather than due to a lack of affordability.

Bhutta et al. (2010) build a theoretical model of mortgage borrower default decisions combining unaffordability and strategic reasons for default. They test the model using a loan-level database, combined with micro-regional property price indices, covering several US states with large property price declines (and business cycle recessions) in the post-2007 period. They find that, considered separately, income distress is the more important source of default decisions, but that strategic default also plays a prominent role at high loan-to-value ratios. They find that when negative equity exceeds $50 \%$ of the property's value, half of the defaulters are exercising their put option rather than experiencing any inability to pay. Also, Bhutta et al. argue that their empirical findings support Foote's (2008) dual-trigger model of default - default is highest when householders experience both simultaneous income falls and negative equity increases. The two causes of default interact and reinforce each other.

Bhutta et al. note that a contributory factor in strategic default is the long "free-rent" period between original default and repossession; this period lasts at least eight to twelve months in most US states, dependent upon the specific legal statutes of the state. The implicit cash value of the free-rent period adds to the put payoff from default and further incentivizes strategic default. Cutts and Merrill (2008) look in detail at cross-state differences in the length of the free-rent period associated with necessary legal delays in the repossession process. They find that states with relatively shorter periods have generally better outcomes in terms of cure-rates (the proportion of households with mortgages in arrears that get back on track and keep their property). They estimate an "optimal" repossession interval of 270 days from original missed payment to physical repossession, consisting of 150 days of customer counseling/assistance with mortgage arrears, a default declaration notice by the lender, and then 120 days before physical repossession.

Relying on survey data, Guiso et al. (2009) find that social considerations, such as morality and fairness, influence borrowers on the acceptability of strategically 
defaulting. They estimate that in their sample $26 \%$ of existing defaults are strategic. They find that almost no households will deliberately choose to default (given ability to pay) if negative equity shortfall is less than $10 \%$ of the value of the house; $17 \%$ of households will choose to default even if they can afford to pay their mortgage when negative equity reaches $50 \%$ of the value of the property. Burke and Mihaly (2012), also based on survey data, find that social perceptions about the acceptability of strategic default, and financial literacy (the ability to navigate the US bankruptcy system) influence household's tendency toward strategic default. Seiler et al. (2012) report that networks are an important determinant of strategic default: borrowers who have family and friends in default are more likely to strategically default themselves. Towe and Lawley (2010) also find that social interactions play a significant role in the decision to default, in that having a neighbor in foreclosure increases the probability of default by $28 \%$.

Elul et al. (2010) use an econometric framework somewhat similar to our own. They define default as accumulated arrears of 60 days or more, and estimate a logit model of binary default outcomes based on individualcredit-record data, together with nationwide quarterly interest rate data and quarterly US state-level unemployment rate changes. They find that both negative equity, which they interpret as strategic default, and inability to pay have a significant effect on mortgage default probability. They also find that the two causes interact, so that mortgage default rates are particularly high when negative equity is combined with stressed ability to pay. Elul et al. also explore the possibility of a nonlinear impact of negative equity on mortgage default rates and find some confirmatory evidence.

We follow Elul et al. in interpreting the relationship between negative equity and default as indicative of a strategic motive for default; this interpretation is also supported by survey evidence, e.g., Guiso et al. (2009). We note however that there can also be some role for negative equity as a causal factor in distressed default: an incomedistressed mortgage holder with positive equity has the option to sell the property and completely erase the debt whereas this option is not available to a mortgage holder with negative equity.

Trautmann and Vlahu (2011) build a game-theoretic model of borrower runs: the tendency of borrowers to deliberately choose default when they perceive balance sheet weakness at the lending bank. Borrowers know that weak banks are likely to be less aggressive in quickly repossessing property, and also that the long-term relationship of the borrower with the bank has less value if the bank is weak. Since borrower loan nonpayments aggravate the weakness of the bank's balance sheet, borrower runs can self-reinforce in the same way as bank depositor runs.

The bargaining-game perspective of Trautmann and Vlahu highlights an important bargaining-game benefit to strategic default which increases as the moneyness of the implicit put option increases. Mortgage borrowers are aware that the lending bank must pay a large transactions cost in repossessing a property, and that the bank would benefit if it could negotiate reduced-value payment terms rather than repossess a negative-equity property. If the bank does not have full recourse to all the borrower's future income, then negative equity in the loan creates a gap between the present value of full mortgage payments and the present value of the minimum mortgage payments that the bank will hypothetically accept to avoid costly repossession. Strategic default (particularly in Ireland where repossession is very costly and difficult for banks) can be employed as a credible threat in negotiations for improved payment terms. Given the structure of Irish mortgage contracts (limited recourse, very costly repossession, banks with weak balance sheets) this is likely to be an important consideration in the Irish case.

Lydon and McCarthy (2011) provide an analysis of Irish mortgage market default based on data collected from four Irish banks during the Central Bank of Ireland's 2010 stresstesting review of the domestic banking sector. Like Elul et al. (2010) and this paper they use a static probit model of mortgage default based on individual loan characteristics. They argue that their static probit model results support a dualtrigger model of default in which both unaffordability and strategic motives (i.e. high loan-to-value ratios) impact household mortgage default. They also find that the regional unemployment rate, as a proxy for local economic shocks, has an impact on regional average default rates. Using a dynamic model applied to regional loan portfolios rather than individual loans, they can not confidently identify a strategic motive for default, but the effect is statistically significant for regional buy-to-let loan portfolios.

One obvious concern is the applicability of US-based research for modeling the default behavior of Irish mortgage borrowers. There are important social, cultural, regulatory, and legal differences between U.S. and Irish residential mortgage markets. The Irish legal and regulatory environment has not been constant over the our sample period. Starting with the 2009 Land Reform Act, which contained a legal flaw rendering residential property repossession virtually impossible in Ireland, there have been a variety of changes to repossession, bankruptcy, and personal insolvency laws and regulation. The legal flaw in the 2009 Land Reform Act was eventually removed after sustained pressure from Ireland's international lenders (the International Monetary Fund, European Central Bank and European Union) under the sovereign bail-out programme. From an international perspective, the current Irish system is borrower-friendly and repossession is slow and costly; see Mac Coille et al. (2013) for a review. Coincidentally or otherwise, during the economically-turbulent period in which these regulatory and legal changes to mortgage contract enforcement were implemented, Irish mortgage arrears grew explosively. Fig. 1 compares the time-series patterns of Irish mortgage defaults, the unemployment rate, per capita real income, and residential property prices over the period Q4 2002 - Q2 2013; all the macroeconomic series are normalized to 100 at the starting date of mortgage default data availability, Q3 2009, while the default rate is plotted on the secondary (right) vertical axis. The rapid increase in mortgage defaults occurs alongside a prolonged period of rising unemployment, falling house prices and falling or stagnant real income. 


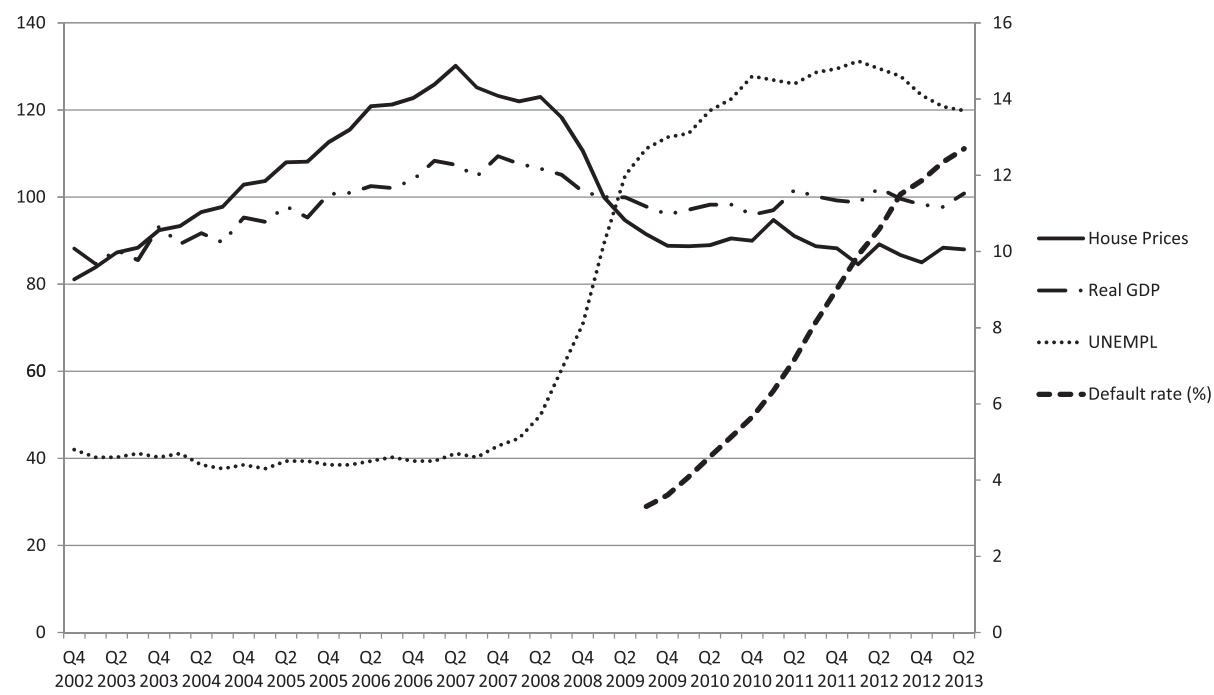

Fig. 1. Comparative time series of Irish residential property price index, unemployment rate, Per-capital real income and home loan default rate.

\section{Linear, nonparametric, and partially linear index probit models of mortgage default}

\subsection{Linear index probit: a brief review}

Our main econometric model is a linear-index probit model of default. We assume that for each mortgage, the borrower's default outcome is based on an unobserved (by the econometrician) decision index $v_{i}$; if $v_{i}>0$ then the mortgage holder defaults. Each borrower's decision index is a linear combination of a $k$ - vector of explanatory variables $x_{i}$ with linear coefficients $\beta$ plus an unobservable individual-specific random component $\varepsilon_{i}$ capturing default-relevant idiosyncratic effects:

$v_{i}=\beta_{0}+\beta^{\prime} x_{i}+\varepsilon_{i}$

and we assume that $\varepsilon_{i}$ has a standard normal distribution and is independent across mortgage borrowers. Let $d_{i}$ denote the observable binary variable which is 1 if the borrower has defaulted and 0 otherwise. Let $\Phi(\cdot)$ denote the cumulative probability function of a standard normal variate. Given observation of $\left\{d_{i}, x_{i}\right\}_{i=1, \ldots, n}$ maximum likelihood estimation of $\left(\beta_{0}, \beta\right)$ is straightforward:

$$
\begin{aligned}
\left(\beta_{0}, \beta\right)= & \underset{\left(\beta_{0}, \beta\right)}{\arg \max } \frac{1}{n} \sum_{i=1}^{n} d_{i} \log \left(\Phi\left(\beta_{0}+\beta^{\prime} x_{i}\right)\right)+\left(1-d_{i}\right) \\
& \times \log \left(1-\Phi\left(\beta_{0}+\beta^{\prime} x_{i}\right)\right)
\end{aligned}
$$

which is easily solved by nonlinear maximization and gives consistent, asymptotically normal estimates with consistently-estimated standard errors, see, e.g., Greene (2008).

In practice, mortgage holders face an intertemporally linked series of choices, each month choosing either to overpay, fully pay, partially pay, or not pay their monthly mortgage payment due. The mortgage holder is in default, under our definition, when the accumulated balance of unpaid arrears is greater than or equal to three times the current required monthly payment. We follow a fairly common research strategy and simplify this intertemporal choice problem by modeling it as a static default/nondefault choice. Specifying and estimating a dynamic intertemporal model of each monthly payment decision would greatly complicate the analysis and is not empirically feasible with our limited dataset.

Readers who are not interested in the econometric technicalities required to allow nonlinearity in the decision index (1) may wish to skip ahead to the next section, which presents the empirical findings.

\subsection{Nonparametric estimation of the link between loan-to- value and default}

A potential weakness of standard probit, in our application, is the assumption of a linear decision index (1). Options pricing theory predicts that the put-option component of the value of default depends nonlinearly upon the loan-to-value ratio. The exact nonlinear shape is not possible to derive due to the complexity of the embedded put option. The put-option-based value of default is near zero for loan-to-value below one and then slopes positively. There is corresponding empirical evidence from US research that strategic mortgage default is nonlinear in the loan-to-value ratio, which again argues against the linearity assumption in the decision index.

In this subsection we analyze a probit model with a fully nonparametric decision index. This model is theoretically estimable by maximum likelihood, see Matzkin (1992), but it is not feasible in our application due to the curse of dimensionality (we have six explanatory variables). Nonetheless we can use the general model to estimate the conditional expected rate of default as a function of loan-to-value. This conditional expectation function is estimable, and can be compared to the predicted conditional expectation function implied by the linear-index probit model. Comparison of the two estimates of this conditional expectation function provides the basis for a nonparametric test of index-linearity of the probit 
model. We are able to test the linear-index probit model against a general nonparametric alternative without being able to completely estimate the nonparametric alternative.

We replace the linear decision index with a nonlinear generalization:

$v_{i}=f\left(x_{i}\right)+\varepsilon_{i}$

where $f(\cdot)$ is a thrice continuously differentiable multivariate function. We continue to assume that $\varepsilon_{i}$ has a standard normal distribution and is independent across $i$. We assume that for each $i$ the vector of explanatory variables $x_{i}$ is a realization from a multivariate joint distribution, independent of $\varepsilon_{i}$ :

$x_{i} \sim D$,

with the restrictions on $D$ described later. Let the first component of $x_{i}$, that is $x_{1 i}$, be the loan-to-value ratio. Note that conditional upon a realized value of $x_{i}$ and given knowledge of $f(\cdot)$, the probability distribution for $d_{i}$ has the same form as in the case of the linear-index probit:

$\operatorname{Pr}\left(d_{i}=1\right)=\Phi\left(f\left(x_{i}\right)\right)$,

recall that $\Phi(\cdot)$ denotes the cumulative normal probability function. Since $d_{i}$ is a binomial zero-one this implies:

$E\left[d_{i} \mid x_{i}\right]=\Phi\left(f\left(x_{i}\right)\right)$.

Recall that we assume that $f(\cdot)$ is a smooth multivariate function. We require that the joint density of the explanatory variables, $D$, is sufficiently smooth so that the following conditional expectation is well-defined and thrice continuously differentiable in $x_{1 i}$ :

$g\left(x_{1 i}\right)=E\left[E\left[d_{i} \mid x_{i}\right] \mid x_{1 i}\right]=E\left[\Phi\left(f\left(x_{i}\right)\right) \mid x_{1 i}\right]$.

Nonparametric regression provides a natural method for estimating $g\left(x_{1 i}\right)$ based on the conditional moment expression (4). In large samples, the conditional expected default at a particular point $\bar{x}_{1 i}$ is consistently estimated by the local-weighted average default in the neighborhood of $\bar{x}_{1 i}$ :

$p \lim _{n \rightarrow \infty} \frac{1}{S_{n}} \sum_{j=1}^{n} d_{j} \kappa\left(x_{1 j}, \bar{x}_{1 i}\right)=g\left(\bar{x}_{1 i}\right)$

where $\kappa\left(x_{1 j}, \bar{x}_{1 i}\right)=\operatorname{dens}\left(\frac{x_{1 j}-\bar{x}_{1 i}}{h_{n}}\right)$ for some density function $\operatorname{dens}(\cdot)$ and bandwidth $h_{n}$, and sum of weights $S_{n}=\sum_{j=1}^{n} d_{j} \kappa\left(x_{1 j}, \bar{x}_{1 i}\right)$. See the Technical Appendix for conditions guaranteeing the consistency and asymptotic normality of the estimator (5).

Note that this fully nonparametric model encompasses the linear-index probit model as a special case. This allows us to test the linear decision index against a fully nonlinear alternative without maximum likelihood estimation of (3). First estimating the linear index probit model by maximum likelihood (2), we then use the same kernel regression to estimate the conditional expectation function using the estimated linear index probit model. Any difference between these two nonparametric estimates of the conditional expectations function captures a linear model bias of the probit model. Under the joint assumptions of this subsection and of the probit model in Section 3.1 above: $p \lim _{n \rightarrow \infty} \frac{1}{S_{n}} \sum \Phi\left(\widehat{\beta}_{0}+\widehat{\beta}^{\prime} x_{j}\right) \kappa\left(x_{1 j}, x_{1 i}\right)=g\left(\bar{x}_{1 i}\right)$

where the kernel regression terms are identical to (5) above. See the Technical Appendix for conditions guaranteeing consistency of the estimator (6). The difference between the unrestricted (5) and restricted (6) estimates of $g\left(x_{1 i}\right)$ we call the linear model bias.

\subsection{Partially linear index probit: a brief review}

There are a number of semiparametric extensions of the standard linear probit model, designed to add flexibility to the functional form without unduly sacrificing estimation accuracy. The partially linear index probit model is a particularly appropriate model choice in our application. It sacrifices some of the flexibility of the fully nonparametric model discussed in the last subsection, by imposing linearity on all but one of the explanatory variables. The decision index is assumed to take the following additive semiparametric form:

$v_{i}=f\left(x_{1 i}\right)+\beta_{(1)}^{\prime} x_{(1) i}+\varepsilon_{i}$

where $x_{(1) i}$ is a $(k-1)$ - vector of the explanatory variables excluding the loan-to-value ratio $x_{1 i}$ and $\beta_{(1)}$ is a $(k-1)$-vector of associated linear coefficients. The univariate function $f\left(x_{1 i}\right)$ is assumed to be thrice continuously differentiable, and $\varepsilon_{i}$ is standard normal. The intercept $\beta_{0}$ is not included in the model since it is not identifiably separable from $f\left(x_{1 i}\right)$.

We follow the estimation algorithm proposed by Carroll et al. (1997). To get initial values, the linear-index probit model (1) is estimated by maximum likelihood (2). Then for a grid point $\bar{x}_{1 i}$ a local quasi-maximum likelihood problem is solved for scalar estimate $\widehat{f}_{\bar{x}_{1 i}}$ :

$$
\begin{aligned}
\widehat{f}_{\bar{x}_{1 i}}= & \arg \max \frac{1}{S_{n}} \sum_{i=1}^{n} \kappa\left(x_{1 i}, \bar{x}_{1 i}\right)\left\{d_{i} \log \left(\Phi\left(\widehat{f}_{\bar{x}_{1 i}}+\widehat{\beta}_{(1)}^{\prime} x_{(1) i}\right)\right)\right. \\
& \left.+\left(1-d_{i}\right) \log \left(1-\Phi\left(\widehat{f}_{\bar{x}_{1 i}}+{\widehat{\beta^{\prime}}}_{(1)} x_{(1) i}\right)\right)\right\}
\end{aligned}
$$

where $\kappa\left(x_{1 i}, \bar{x}_{1 i}\right)$ is a kernel-weighting scheme and $S_{n}$ is the sum of the kernel weights. This local quasi-maximum likelihood problem is solved for each of a set of finely spaced grid points covering the sample range of $x_{1 i}$. A cross-section of implied estimates for $f\left(x_{1 i}\right)$ is found by interpolating between grid points:

$\widehat{f}\left(x_{1 i}\right)=\widehat{f}_{\bar{x}_{1 i}}+\left(x_{1 i}-\bar{x}_{1 i}\right)\left(\widehat{f}_{\bar{x}_{1 i}^{*}}-\widehat{f}_{\bar{x}_{1 i}}\right)$

where $\bar{x}_{1 i}^{*}>\bar{x}_{1 i}$ are the two contiguous grid points containing $x_{1 i}$. Next, we return to the linear-index probit maximum likelihood problem but replacing $\beta_{0}+\beta_{1} x_{1 i}$ with the pre-estimated $\widehat{f}\left(x_{1 i}\right)$ from (9):

$$
\begin{aligned}
\widehat{\beta}_{(1)}= & \underset{\beta_{(1)}}{\arg \max } \frac{1}{n} \sum_{i=1}^{n} d_{i} \log \left(\Phi\left(\widehat{f}\left(x_{1 i}\right)+\beta_{(1)}^{\prime} x_{(1) i}\right)\right) \\
& +\left(1-d_{i}\right) \log \left(1-\Phi\left(\widehat{f}\left(x_{1 i}\right)+\beta_{(1)}^{\prime} x_{(1) i}\right)\right) .
\end{aligned}
$$

The two steps (8) and (10) are iterated to convergence. See Carroll et al. (1997) and Bellemare et al. (2002) for discussion of convergence properties, optimal bandwidth choice, 
and related issues. Our estimates appear in the next section.

\section{Empirical analysis of Irish mortgage defaults}

\subsection{The database and key variables}

Our database was provided by Permanent TSB bank and consists of all property loans at Permanent TSB in September 2013 that have submitted a Standard Financial Statement (SFS). The bank collates the information in the SFS with existing bank information on the loan account, including application information and payment records.

The Central Bank of Ireland mandates that all mortgage lenders must collect an SFS from each home loan mortgage borrower in arrears, as part of the Mortgage Arrears Resolution Process (MARP). MARP is the Central Bank mandated process that all regulated mortgage lenders must follow in dealing with customer mortgage payment difficulties. Each regulated mortgage lender must treat every mortgage loan which has been in arrears (for any amount) for more than 31 calendar days as in MARP, and must write to the mortgage borrower within 3 business days after these 31 days are elapsed and tell them that they are covered by MARP. The lender must provide an SFS to the borrower in MARP, give them assistance in filling out the SFS as needed, and then must pass the completed SFS to the Arrears Support Unit within the lending bank which must follow specific regulations in dealing with each MARP case. If the mortgage borrower fails to return the SFS then they can be classified under Central Bank of Ireland regulations as a noncooperative borrower and borrower protections under MARP may be lifted. Mortgage borrowers may also voluntarily submit an SFS, for example in order to negotiate mortgage restructuring without falling into arrears.

SFS coverage encompasses, at least in theory, any mortgage borrower who misses any part of a mortgage payment, as long as the missed payment is not rectified within 31 days. It also encompasses all borrowers negotiating for mortgage payment alterations. Ireland does not yet have a national credit register database, and under European data rules Irish banks are restricted in the information that they can keep regarding the current financial situation of existing borrowers (other than information received at loan origination). The SFS database allows us to link the current financial situation of borrowers with their mortgage application data and mortgage payment histories. The database is limited in some ways as we discuss below, but it still provides valuable insight into mortgage default behavior during a tumultuous period in Irish financial history.

There are a total of 28,377 loan accounts in the database, 25,235 home loan accounts and 3,142 residential property investor loan accounts (called buy-to-let loans). Mortgage borrowers with both home and buy-to-let loans are included in the buy-to-let loans figure. For each multiple-loan account we aggregate the individual loan characteristics and effectively treat it as one loan observation. Taking account of borrowers with multiple loans the database covers 37,547 individual home loans and 4,285
Table 1

Percentage distributions of loan type and default rates.

\begin{tabular}{llll}
\hline & $\begin{array}{l}\text { All loans } \\
(\%)\end{array}$ & $\begin{array}{l}\text { Home } \\
\text { loans (\%) }\end{array}$ & $\begin{array}{l}\text { Buy-to-let } \\
\text { loans (\%) }\end{array}$ \\
\hline $\begin{array}{l}\text { All loans } \\
\text { \% Loans in default in the } \\
\text { category }\end{array}$ & $\begin{array}{c}\text { 400 } \\
\text { cals }\end{array}$ & 88.9 & 11.1 \\
\hline
\end{tabular}

individual buy-to-let loans; this compares to a total outstanding portfolio of 140,060 home loans and 23,133 buy-to-let loans at Permanent TSB, so $23.7 \%$ of the bank's total home loans portfolio are in the database and $18.5 \%$ of its buy-to-let loans portfolio. The database includes a default dummy for any loan that has accumulated arrears of greater than 90 days. A multiple account is treated as in default if accumulated arrears on any of the loans is greater than 90 days of required payments. Table 1 shows the percentages of the two loan types in default in the database. In the Permanent TSB total loan book, $15.3 \%$ of home loans and $17.9 \%$ of buy-to-let loans are in default; this of course differs sharply from our database (SFS-linked loans only) with $48.7 \%$ of home loans and $49.9 \%$ of buy-tolet loans in default.

The default dummy signifies whether the mortgage account has greater than 90 days arrears on the database sampling date, which is September 2013. The database also includes the month in which the SFS was submitted and whether or not the mortgage account was in default on the SFS submission date. Fig. 2 shows the SFS submission numbers each month from the initiation of MARP until September 2013. Most of the SFS were submitted during the second half of the period. Fig. 3 display the patterns of default as a function of the SFS submission date. Mortgage accounts from an SFS submitted in the earlier months have lower initial default rates (that is, fewer are in default on their SFS date), but a higher proportion enter default between their SFS date and September 2013 which is the date used to measure default in our empirical analysis. For all SFS submission months, only a small proportion of mortgages exit default between their SFS submission month and September 2013. The net effect of these offsetting trends leaves the proportion of mortgages in default in September 2013 with a moderate, generally upward, trend as a function of their SFS submission date.

In addition to the default dummy, the database has the "number of days" of accumulated arrears $(30 \times$ arrears amount/monthly required payment) as of September 2013. Table 2 summarizes this data. This measure has the advantage over the default dummy that it captures the level of accumulated arrears rather than only giving a binary indicator of default. However, the range of values runs very high - half of the mortgages in arrears have almost a year (314 days) of accumulated arrears. The difference between a loan that is five years in arrears and a loan which is one year in arrears seems mostly a matter of timing for when the default began, rather than a different decision by the mortgage borrower. Also, there is extant research literature on mortgage loan default but no comparable non-Irish data or research on multi-year 


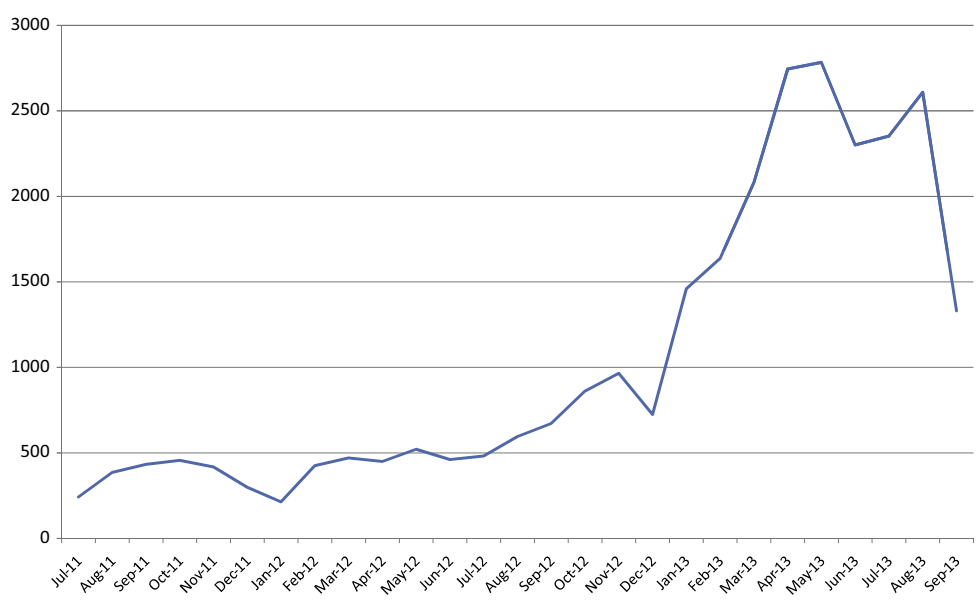

Fig. 2. Number of SFS submitted by month.

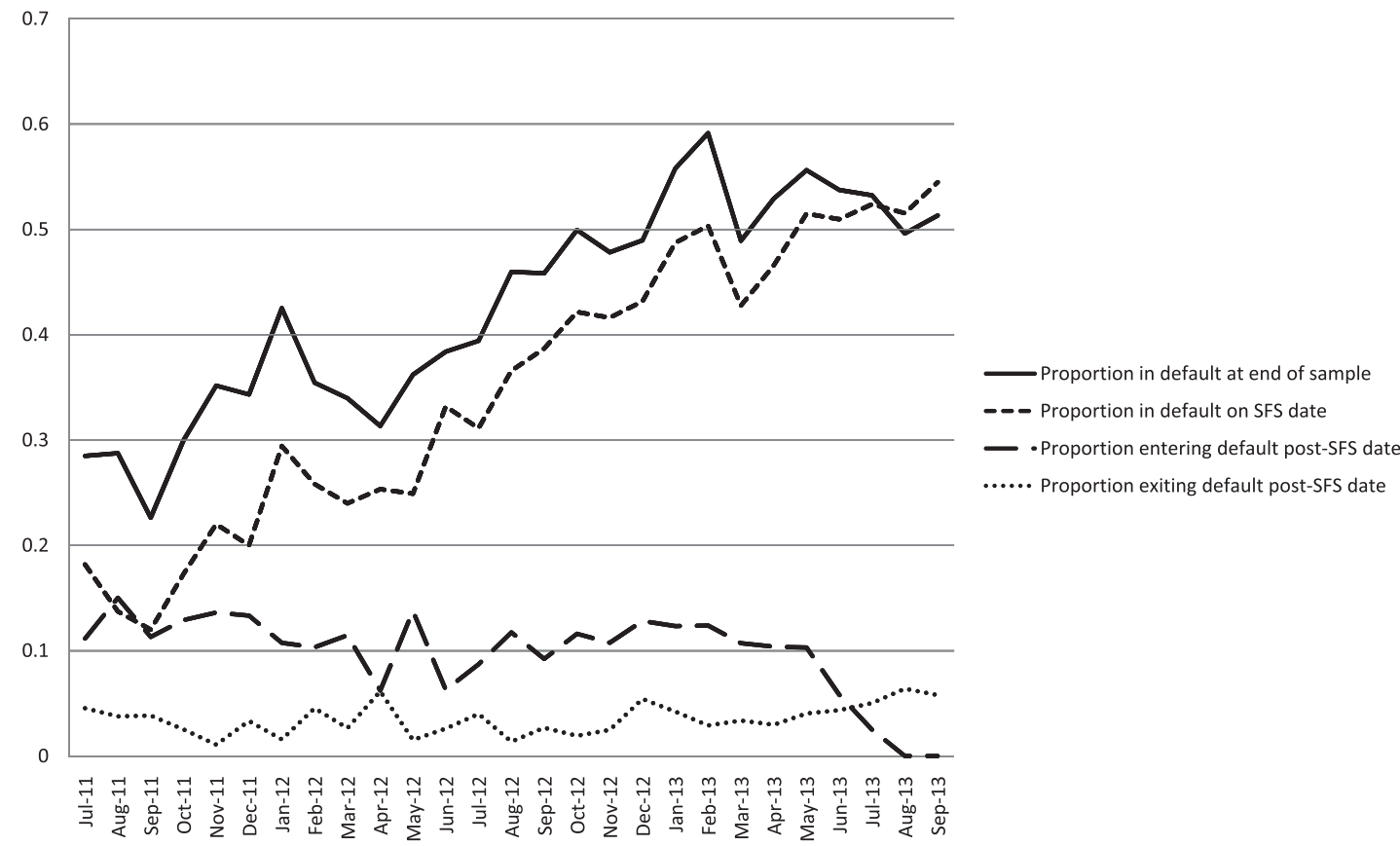

Fig. 3. Default patterns by SFS submission month.

accumulated arrears. Hence we focus on models explaining loan default rather than accumulated arrears. ${ }^{2}$

There are two sources of sample selection in our database, both of which limit the general applicability of our empirical analysis. First, we only have information on mortgages for which there is an SFS on file at the bank. In the absence of an SFS, there is no current information available for the borrower. Completely non-distressed mortgages do not appear in our database, and so we do

\footnotetext{
2 We also considered modeling the "cures" (i.e. mortgages in default on the SFS date that are performing by end of sample) but our sample covers a period with very few reliably-identifiable, successful cures. Greater detail is given in the unpublished appendix, Connor and Flavin (2014).
}

not model their holders' decision-making in choosing non-default.

The second source of sample selection comes from imperfect compliance with the Central Bank of Ireland requirement for an SFS for each troubled mortgage. It is not possible from the database to compute the compliance rate for all mortgage types since SFS submissions can be required by the bank or voluntarily chosen by the mortgage borrower. One exception is home mortgages in default, where submission of an SFS is mandated in all cases by MARP. Permanent TSB records 21,398 home loan accounts in default, but have only 14,996 SFS submissions from home loan mortgage borrowers in default, giving an SFS submission compliance rate of $70.1 \%$ for this subcategory. The potential statistical interaction between the 
Table 2

Statistical distribution of days in arrears for loan accounts with nonzero arrears.

\begin{tabular}{lccc}
\hline & All loans & Home loans & Buy-to-let loans \\
\hline 10\% Fractile & 34 & 34 & 40.6 \\
25\% Fractile & 110 & 106 & 150 \\
Median & 314 & 305 & 423 \\
Mean & 451.8 & 443.8 & 516.8 \\
$75 \%$ Fractile & 662 & 642 & 766.3 \\
$90 \%$ Fractile & 1037 & 1034 & 1095 \\
\hline
\end{tabular}

non-cooperation decision of mortgage borrowers in arrears and our model of their default decision (based only on data for those who have complied) limits the applicability of our results for mortgages outside the conditioning set. It seems possible that non-cooperation is more tempting for borrowers with certain characteristics, which may also impact their default decision-making. In the econometrics literature this type of endogenous sample selection is called self-selection, see Cameron and Trivedi (2005, chapter 16) for an overview. We can only offer the caveat that our model is of borrower default outcomes conditional upon their submitting an SFS, and is not dependable for non-cooperating borrowers, who are outside this conditioning set.

We rely on six explanatory variables for loan default. Application LTV is the loan-to-value ratio at the time the loan was issued (we also have the date of issue, which we use in Table 3 below). LTV is the estimated current loan to value ratio. The current loan-to-value ratio takes the most recent physical valuation of the property available to the bank (for the majority of loans this will be the valuation done at the application date, but it may be more recent) and then uses a property price index to adjust forward the valuation to account for price increases and/or decreases since the physical valuation date. The forward price adjustment uses the most relevant of the following four property price indices for each individual property: Dublin houses, Dublin apartments, non-Dublin houses, and non-Dublin apartments. The loan amount is adjusted for amortization or reverse-amortization of the capital balance using the bank's payment records on the individual loan.

The payment-to-income index, or affordability index for short, is defined as required payment commitments divided by net income. Net income is the after-tax income of the borrower (or multiple borrowers). The definition of required payment commitments differs between home and buy-to-let loans:

Required payment commitments for home loans = existing short term debt payments + existing mortgage payments + existing buy-to-let deficit + maintenance costs + proposed buy-to-let deficit + proposed mortgage payments - tax relief

Required payment commitments for buy-to-let loans = existing short term debt payments + existing mortgage payments + existing buy-to-let deficit + maintenance + proposed buy-to-let deficit - tax relief.

The same formulas are used for the application values and current values of the affordability index. The current values are at the date on which the most recent SFS was received, and use information provided by the household on this form.

The loan-to-value ratios for a multiple-loan account are computed as the sum of the multiple loan amounts divided by the sum of the property values, both currently and at the application date of the most recent loan. The affordability ratio for a multiple-loan account sums the required payment commitments from all the loans and then divides by net income.

We examined the database for data outliers and other discernible errors. The only notable problem we could identify was that 0 had been used in some cases in place of missing data. Since all six of our explanatory variables should be strictly positive, except in most unusual circumstances, we treat all zero entries as missing. We truncated application LTV and LTV at 5.0, and the affordability index at 3.0, to dampen the influence of extreme values (which may be data errors) on the estimation routines. Table 3

Table 3

Data distribution of each explanatory variable across years of loan origination.

\begin{tabular}{|c|c|c|c|c|c|c|}
\hline Year & $\begin{array}{l}\text { Application payment-to- } \\
\text { income ratio (\%) }\end{array}$ & $\begin{array}{l}\text { Application loan-to- } \\
\text { value ratio (\%) }\end{array}$ & $\begin{array}{l}\text { Application net } \\
\text { income (\%) }\end{array}$ & $\begin{array}{l}\text { Payment-to-income } \\
\text { ratio (\%) }\end{array}$ & $\begin{array}{l}\text { Loan-to-value } \\
\text { ratio (\%) }\end{array}$ & $\begin{array}{l}\text { Net } \\
\text { income } \\
(\%)\end{array}$ \\
\hline $\begin{array}{l}1999 \text { or } \\
\text { earlier }\end{array}$ & 5.27 & 3.72 & 3.08 & 5.27 & 5.27 & 5.15 \\
\hline 2000 & 2.55 & 2.55 & 2.17 & 2.55 & 2.55 & 2.48 \\
\hline 2001 & 2.75 & 2.74 & 2.39 & 2.75 & 2.75 & 2.68 \\
\hline 2002 & 3.65 & 3.65 & 3.22 & 3.65 & 3.65 & 3.58 \\
\hline 2003 & 5.98 & 5.98 & 5.89 & 5.98 & 5.98 & 5.84 \\
\hline 2004 & 8.76 & 8.76 & 8.75 & 8.76 & 8.76 & 8.61 \\
\hline 2005 & 13.92 & 13.92 & 13.92 & 13.92 & 13.92 & 13.67 \\
\hline 2006 & 21.30 & 21.30 & 21.29 & 21.30 & 21.30 & 20.90 \\
\hline 2007 & 19.00 & 19.00 & 18.88 & 19.00 & 19.00 & 18.58 \\
\hline 2008 & 13.22 & 13.22 & 12.87 & 13.22 & 13.22 & 13.00 \\
\hline 2009 & 2.83 & 2.83 & 2.82 & 2.83 & 2.83 & 2.77 \\
\hline 2010 & 0.53 & 0.53 & 0.52 & 0.53 & 0.53 & 0.52 \\
\hline 2011 & 0.15 & 0.15 & 0.15 & 0.15 & 0.15 & 0.15 \\
\hline 2012 & 0.07 & 0.07 & 0.06 & 0.07 & 0.07 & 0.07 \\
\hline 2013 & 0.02 & 0.00 & 0.00 & 0.02 & 0.02 & 0.02 \\
\hline Missing & 13.68 & 1.59 & 3.98 & 2.02 & 0.00 & 2.02 \\
\hline Truncated & 0.11 & 0.02 & 0.00 & 2.45 & 0.41 & 0.00 \\
\hline
\end{tabular}


Table 4

Descriptive statistics of explanatory variables.

\begin{tabular}{|c|c|c|c|c|c|c|}
\hline & Bottom quartile & Median & Top quartile & Mean & Standard deviation & Number of observations \\
\hline Application date loan-to-value & .420 & .640 & .880 & .631 & .256 & 28,061 \\
\hline Current loan-to-value & .620 & 1.02 & 1.42 & 1.04 & .570 & 28,377 \\
\hline Application date payment-to-income & .290 & .340 & .370 & .336 & .141 & 25,549 \\
\hline Current payment-to-income & .280 & .380 & .540 & .471 & .351 & 27,879 \\
\hline Application date net income & $€ 2664$ & $€ 3517$ & $€ 4473$ & $€ 3843$ & $€ 3390$ & 27,725 \\
\hline Current net income & $€ 1802$ & $€ 2529$ & $€ 3480$ & $€ 2840$ & $€ 1868$ & 27,879 \\
\hline
\end{tabular}

Table 5

Correlation matrix of the explanatory variables.

\begin{tabular}{lccccc}
\hline & LTV & $\begin{array}{l}\text { Application date } \\
\text { LTV }\end{array}$ & Affordability & $\begin{array}{l}\text { Application date } \\
\text { affordability }\end{array}$ & $\begin{array}{l}\text { Log } \\
\text { income }\end{array}$ \\
\hline LTV & 1.000 & & & \\
Application date LTV & 0.655 & 1.000 & 1.000 & \\
Affordability & 0.113 & 0.039 & 0.109 & 1.000 \\
$\quad \begin{array}{l}\text { Application date } \\
\quad \text { affordability }\end{array}$ & 0.081 & 0.020 & -0.556 & 0.073 & 1.000 \\
Log income & 0.076 & 0.012 & 0.014 & 0.012 & 0.164 \\
Application date log income & 0.123 & 0.096 & & 1.000 \\
\hline
\end{tabular}

Table 6

Default rates for loans doubly-sorted by loan-to-value, payment-to-income and net income: full sample.

\begin{tabular}{|c|c|c|c|}
\hline & Low payment-to-income (\%) & Moderate payment-to-income (\%) & High payment-to-income (\%) \\
\hline \multicolumn{4}{|c|}{ a:Default rates for loans sorted by loan-to-value and affordability } \\
\hline Low LTV & 43.43 & 39.04 & 46.03 \\
\hline Moderate LTV & 41.55 & 43.98 & 57.34 \\
\hline High LTV & 47.40 & 56.47 & 70.55 \\
\hline \multicolumn{4}{|c|}{$\mathrm{b}$ :Default rates for loans sorted by loan-to-value and net income } \\
\hline & High income (\%) & Moderate income (\%) & Low income $(\%)$ \\
\hline Low LTV & 31.91 & 40.26 & 48.85 \\
\hline Moderate LTV & 39.11 & 47.40 & 56.63 \\
\hline High LTV & 51.34 & 59.78 & 69.13 \\
\hline \multicolumn{4}{|c|}{ c:Default rates for loans sorted by affordability and net income } \\
\hline & High income (\%) & Moderate income (\%) & Low income (\%) \\
\hline Low payment-to-income & 38.40 & 42.02 & 51.39 \\
\hline Moderate payment-to-income & 45.11 & 47.31 & 60.27 \\
\hline High payment-to-income & 58.50 & 48.36 & 60.81 \\
\hline
\end{tabular}

Table 7

Proportions of loans in default for subcategory of loan-to-value and increased/decreased affordability.

\begin{tabular}{llll}
\hline Loan type & Change in affordability & Low loan-to-value (\%) & Moderate loan-to-value (\%) \\
\hline Full sample & Increased affordability & 31.00 & 40.89 \\
& Decreased affordability & 37.41 & 49.48 \\
Home loans & Increased affordability & 31.09 & 41.49 \\
& Decreased affordability & 37.72 & 49.18 \\
Buy-to-let loans & Increased affordability & 28.07 & 33.03 \\
& Decreased affordability & 33.33 & 51.16 \\
\hline
\end{tabular}

shows the number of mortgage entries in our database for each year of loan origination, along with the number of data points truncated. The columns in the table differ since some variables have missing data, particularly for application data at earlier loan origination dates. $67 \%$ of the mortgages in the database originate in the 4 years 2005-2008. Table 4 provides descriptive statistics on the six explanatory variables. Table 5 shows the correlation matrix of the explanatory variables. Not surprisingly, application LTV and LTV have a fairly strong cross-sectional correlation of 0.655 . For most of the mortgage accounts in the sample, the difference between these two variables predominantly reflects capital gain or loss on the underlying property, although loan amortization can also be a factor, particularly for older mortgages.

\subsection{Estimation of the model}

As a preliminary step we double-sort all loans using each pair of the three current variables: loan-to-value, 
Table 8

Probit model of default with six explanatory variables.

\begin{tabular}{|c|c|c|c|c|}
\hline Variable & Coefficient & Std error & T-stat & Significance \\
\hline \multicolumn{5}{|l|}{ a: Full sample } \\
\hline App affordability & -0.063 & 0.058 & -1.081 & 0.280 \\
\hline App LTV & -0.617 & 0.043 & -14.261 & 0.000 \\
\hline App log income & 0.016 & 0.011 & 1.471 & 0.141 \\
\hline Affordability & 0.312 & 0.031 & 10.170 & 0.000 \\
\hline LTV & 0.620 & 0.022 & 28.443 & 0.000 \\
\hline Log income & -0.192 & 0.019 & -10.310 & 0.000 \\
\hline Constant & 0.901 & 0.159 & 5.664 & 0.000 \\
\hline Pseudo R-squared & 0.059 & & & \\
\hline No. of observations & 25116 & & & \\
\hline \multicolumn{5}{|l|}{ b:Home loans } \\
\hline App affordability & -0.078 & 0.066 & -1.184 & 0.236 \\
\hline App LTV & -0.619 & 0.046 & -13.531 & 0.000 \\
\hline App log income & 0.019 & 0.021 & 0.895 & 0.371 \\
\hline Affordability & 0.225 & 0.043 & 5.274 & 0.000 \\
\hline LTV & 0.628 & 0.023 & 26.865 & 0.000 \\
\hline Log income & -0.207 & 0.026 & -7.965 & 0.000 \\
\hline Constant & 1.024 & 0.197 & 5.200 & 0.000 \\
\hline Pseudo R-squared & 0.054 & & & \\
\hline No. of observations & 22474 & & & \\
\hline \multicolumn{5}{|l|}{ c:Buy-to-let loans } \\
\hline App affordability & 0.043 & 0.135 & 0.318 & 0.75 \\
\hline App LTV & -0.564 & 0.143 & -3.93 & 0 \\
\hline App log income & 0.021 & 0.013 & 1.663 & 0.096 \\
\hline Affordability & 0.551 & 0.068 & 8.132 & 0 \\
\hline LTV & 0.578 & 0.063 & 9.135 & 0 \\
\hline Log income & -0.205 & 0.048 & -4.222 & 0 \\
\hline Constant & 0.772 & 0.438 & 1.763 & 0.078 \\
\hline Pseudo R-squared & 0.115 & & & \\
\hline No. of observations & 2642 & & & \\
\hline
\end{tabular}

Table 9

Probit model of default with four explanatory variables.

\begin{tabular}{|c|c|c|c|c|c|c|}
\hline Variable & Coefficient & Std error & T-stat & Significance & $\begin{array}{l}\text { Marginal probability } \\
\text { at average values }\end{array}$ & $\begin{array}{l}\text { Average of pointwise } \\
\text { marginal probability }\end{array}$ \\
\hline \multicolumn{7}{|l|}{ a:Full sample } \\
\hline App LTV & -0.394 & 0.039 & -10.096 & 0.000 & -0.15694 & -0.2069 \\
\hline Affordability & 0.227 & 0.027 & 8.312 & 0.000 & 0.09028 & 0.11901 \\
\hline LTV & 0.452 & 0.019 & 23.857 & 0.000 & 0.18012 & 0.23744 \\
\hline Log income & -0.237 & 0.017 & -14.331 & 0.000 & -0.09427 & -0.12427 \\
\hline Constant & 1.484 & 0.136 & 10.932 & 0.000 & & \\
\hline Pseudo R-squared & 0.044 & & & & & \\
\hline No. of observations & 27568 & & & & & \\
\hline \multicolumn{7}{|l|}{ b:Home loans } \\
\hline App LTV & -0.383 & 0.041 & -9.292 & 0.000 & -0.15243 & -0.19891 \\
\hline Affordability & 0.093 & 0.036 & 2.565 & 0.010 & 0.03689 & 0.04814 \\
\hline LTV & 0.458 & 0.020 & 22.585 & 0.000 & 0.18248 & 0.23813 \\
\hline Log income & -0.275 & 0.021 & -13.239 & 0.000 & -0.10964 & -0.14307 \\
\hline Constant & 1.825 & 0.170 & 10.725 & 0.000 & & \\
\hline Pseudo R-squared & 0.039 & & & & & \\
\hline No. of observations & 24515 & & & & & \\
\hline \multicolumn{7}{|l|}{ c:Buy-to-let loans } \\
\hline App LTV & -0.425 & 0.131 & -3.247 & 0.001 & -0.16893 & -0.19999 \\
\hline Affordability & 0.491 & 0.058 & 8.502 & 0.000 & 0.19534 & 0.23126 \\
\hline LTV & 0.483 & 0.056 & 8.588 & 0.000 & 0.19204 & 0.22735 \\
\hline Log income & -0.210 & 0.042 & -4.974 & 0.000 & -0.08373 & -0.09912 \\
\hline Constant & 1.089 & 0.379 & 2.875 & 0.004 & 0.43316 & 0.5128 \\
\hline Pseudo R-squared & 0.102 & & & & & \\
\hline No. of observations & 3053 & & & & & \\
\hline
\end{tabular}

payment-to-income, and log income, and then compute the average default rate within each subset. For each variable the first breakpoint is the $25 \%$ fractile of its univariate distribution and the second breakpoint is the 75\% fractile, so that the middle category captures the interquartile range. The interquartile range is $(0.62,1.42)$ for loan-tovalue, $(0.28,0.54)$ for payment-to-income, and $(\log (1,802)$, $\log (3,480))$ for $\log$ of net monthly income. The results 
Table 10

Logit model of default with four explanatory variables.

\begin{tabular}{|c|c|c|c|c|}
\hline Variable & Coefficient & $\begin{array}{l}\text { Std } \\
\text { error }\end{array}$ & T-stat & Significance \\
\hline \multicolumn{5}{|l|}{ a:Full sample } \\
\hline App LTV & -0.724 & 0.066 & -10.954 & 0.000 \\
\hline Affordability & 0.361 & 0.046 & 7.875 & 0.000 \\
\hline LTV & 0.797 & 0.034 & 23.335 & 0.000 \\
\hline Log income & -0.406 & 0.027 & -14.922 & 0.000 \\
\hline Constant & 2.572 & 0.223 & 11.545 & 0.000 \\
\hline $\begin{array}{l}\text { Pseudo R- } \\
\text { squared }\end{array}$ & 0.046 & & & \\
\hline $\begin{array}{l}\text { No. of } \\
\text { observations }\end{array}$ & 27568 & & & \\
\hline \multicolumn{5}{|l|}{ b:Home loans } \\
\hline App LTV & -0.712 & 0.070 & -10.193 & 0.000 \\
\hline Affordability & 0.125 & 0.060 & 2.085 & 0.037 \\
\hline LTV & 0.811 & 0.037 & 22.069 & 0.000 \\
\hline Log income & -0.467 & 0.034 & -13.703 & 0.000 \\
\hline Constant & 3.123 & 0.279 & 11.211 & 0.000 \\
\hline $\begin{array}{l}\text { Pseudo R- } \\
\text { squared }\end{array}$ & 0.040 & & & \\
\hline $\begin{array}{l}\text { No. of } \\
\text { observations }\end{array}$ & 24515 & & & \\
\hline \multicolumn{5}{|l|}{ c:Buy-to-let loans } \\
\hline App LTV & -0.738 & 0.217 & -3.393 & 0.001 \\
\hline Affordability & 0.843 & 0.102 & 8.286 & 0.000 \\
\hline LTV & 0.860 & 0.100 & 8.601 & 0.000 \\
\hline Log income & -0.407 & 0.073 & -5.543 & 0.000 \\
\hline Constant & 2.225 & 0.649 & 3.430 & 0.001 \\
\hline $\begin{array}{l}\text { Pseudo R- } \\
\text { squared }\end{array}$ & 0.106 & & & \\
\hline $\begin{array}{l}\text { No. of } \\
\text { observations }\end{array}$ & 3053 & & & \\
\hline
\end{tabular}

appear in Table 6. All three of the variables seem to contain information about default rates. The strongest double-sort comes from using loan-to-value and log income together, but all three variables show some explanatory power. The corresponding tables for home loans and buy-to-let loans examined separately are shown in the supplementary tables in the unpublished appendix (Connor and Flavin, 2014).

The results in Table 6a are particularly interesting. For purposes of informal analysis the three columns in the table can be thought of as affordable payment, stressed payment, and unaffordable payment; the three rows can be thought of as positive equity, zero to moderate negative equity, and large negative equity. Note that the $(1,1)$ subset (affordable payment, positive equity) has an average default rate of $43.4 \%$ whereas the $(3,3)$ subset (unaffordable payment, large negative equity) has a default rate of $70.6 \%$. The $(3,1)$ and $(1,3)$ subsets have roughly equal average default rates which are not that much higher than for the $(1,1)$ subset. The big jump in the default rate comes when the loan has both low affordability and large negative equity: the joint effect seems much bigger than the sum of the two individual effects. This conforms to Foote's (2008) dual-trigger model of default, and supports the US-based findings of Bhutta et al. (2010) and Elul et al. (2010). The probit model which we use below also captures this empirical feature.

Table 7 follows on from Table 6a. We subdivide the loans into those that have undergone a decrease in affordability since loan origination (for example due to unemployment, lower household income, or higher short-term debt obligations) and those that have undergone an increase, and look at the default rates for the three levels of current loan-to-value, using the interquartile range for the middle loan-to-value category, as in Table 6. Both decreased affordability and the current loan-to-value ratio have an impact on default rates, and the two effects interact, as in Table 6.

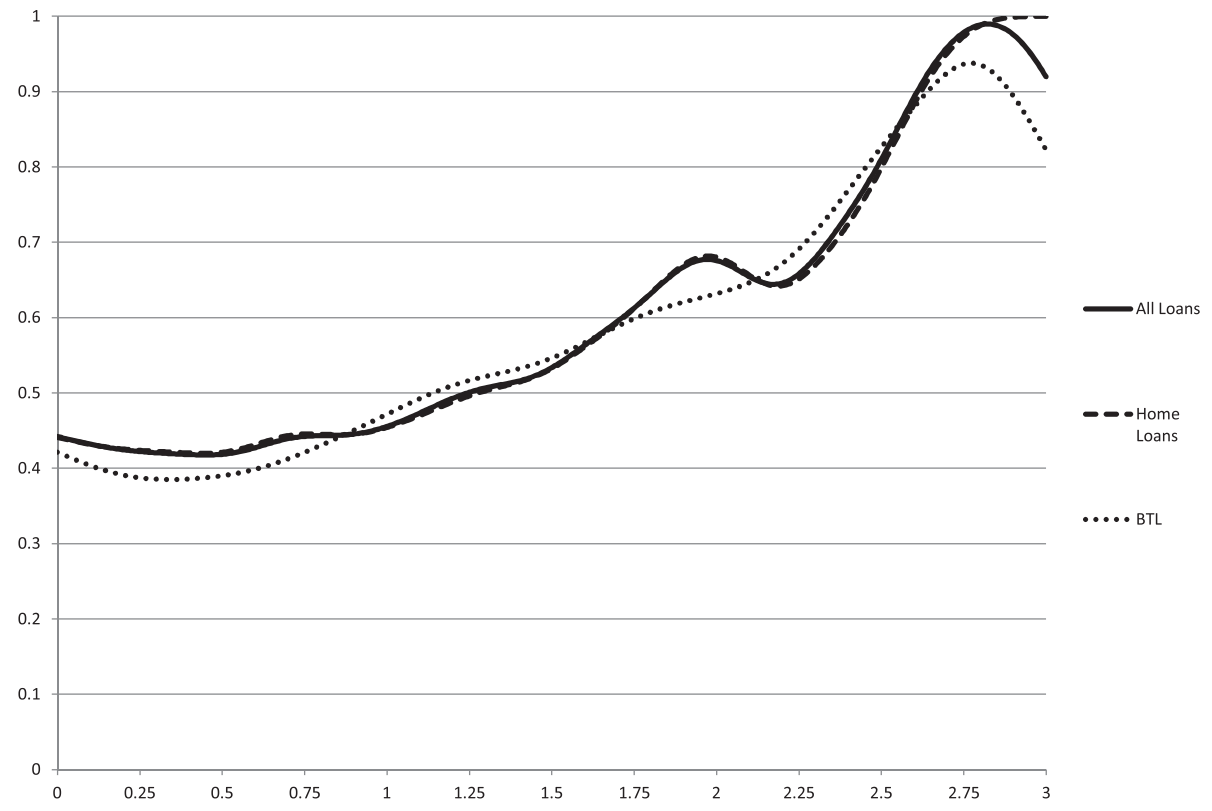

Fig. 4. Local proportion of loans in default as a function of loan-to-value. 


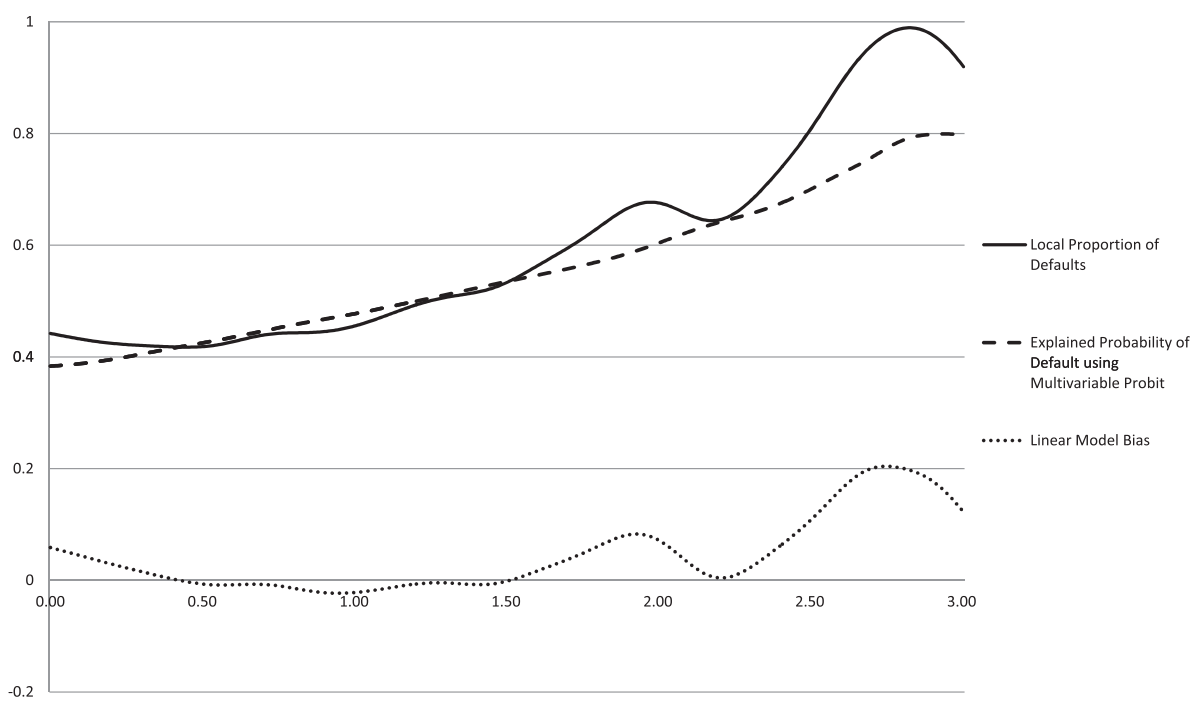

Fig. 5a. Semiparametric estimation of the probability of default as a function of loan-to-value, all loans.

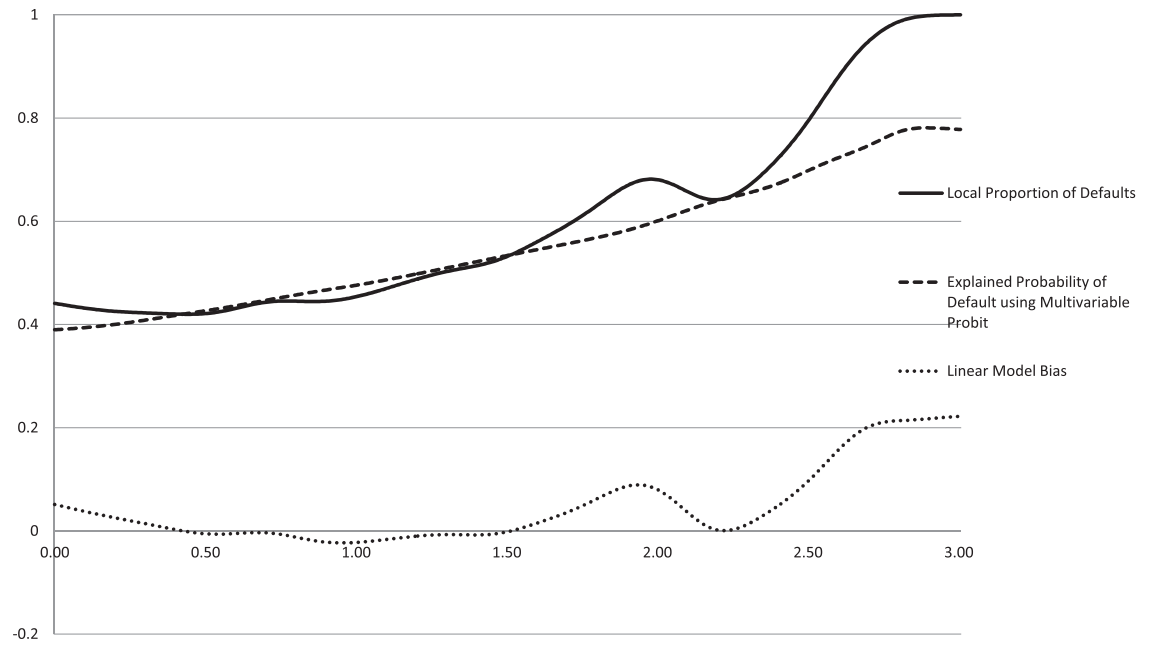

Fig. 5b. Semiparametric estimation of the probability of default as a function of loan-to-value, home loans.

We begin parameterized model estimation using a probit model with all six explanatory variables ${ }^{3}$ :

$$
\begin{aligned}
\operatorname{Prob}\left(\text { default }_{i}\right)= & \Phi\left(\beta_{0}+\beta_{1} \text { LTV }_{i}+\beta_{2} \text { Afford }_{i}\right. \\
& +\beta_{3} \text { LogIncome }_{i}+\beta_{4} \text { AppLTV }_{i} \\
& \left.+\beta_{5} \text { AppAfford }_{i}+\beta_{6} \text { AppLogIncome }_{i}\right) .
\end{aligned}
$$

The results are shown in Table 8 , for all loans in the database, and then for the subsample of home loans and buyto-let loans estimated separately.

Application-date affordability and application-date log income have weak explanatory power in Table 8. In Table 9

\footnotetext{
${ }^{3}$ For robustness, we estimate this model on the full sample and two subsamples (home loans and buy-to-let loans) using three methods (probit, logit, and linear-probability ordinary least squares) and show estimation results for each in an unpublished appendix. The results are quite uniform across the three subsamples and three estimation techniques.
}

we re-estimate the probit models dropping these two variables. In Table 10 we show estimates of this same model using the logistic distribution in place of the normal distribution. We will focus on the probit model with four explanatory variables (Table 9 ).

The last two columns in Table 9 show the marginal impact on default probability of a marginal change in each explanatory variable, calculated two ways: using the sample average of the other explanatory variables, and computed individually at each sample point and then averaged across the sample. Both measures are used in the literature but the latter is generally considered preferable; see Greene (2008). Current log income has more impact on the default decision than the current affordability index. A strong and surprising finding is the notable power of current loan-to-value in determining Irish mortgage default decisions, as measured by these marginal 


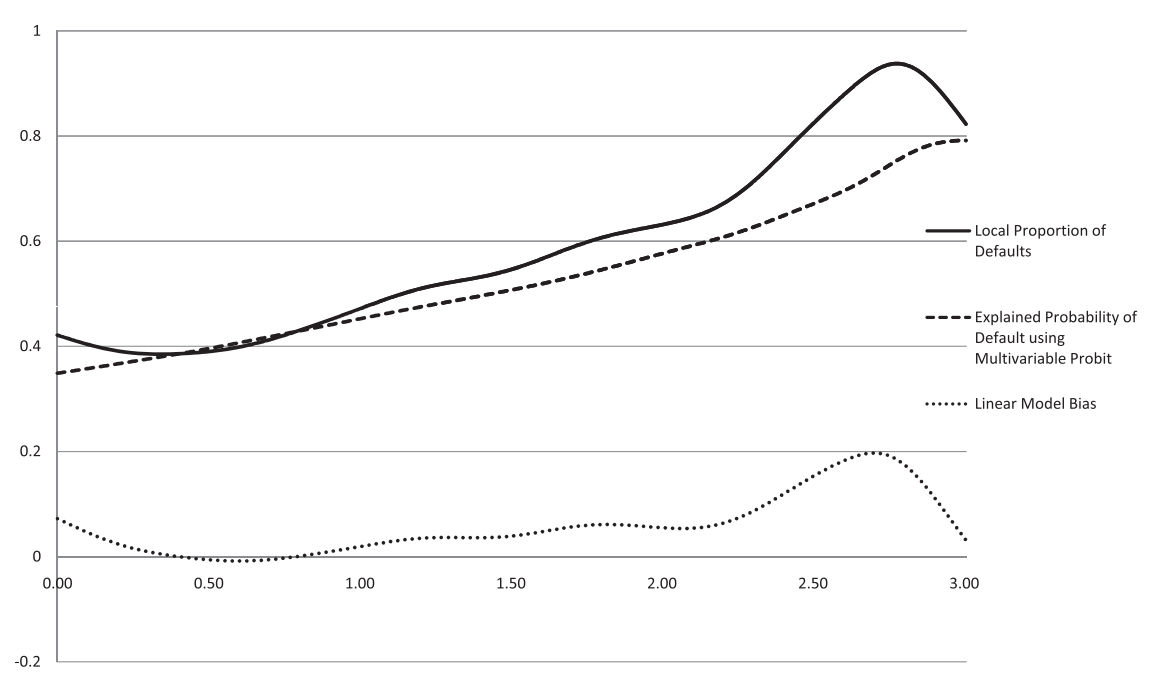

Fig. 5c. Semiparametric estimation of the probability of default as a function of loan-to-value, buy-to-let loans.

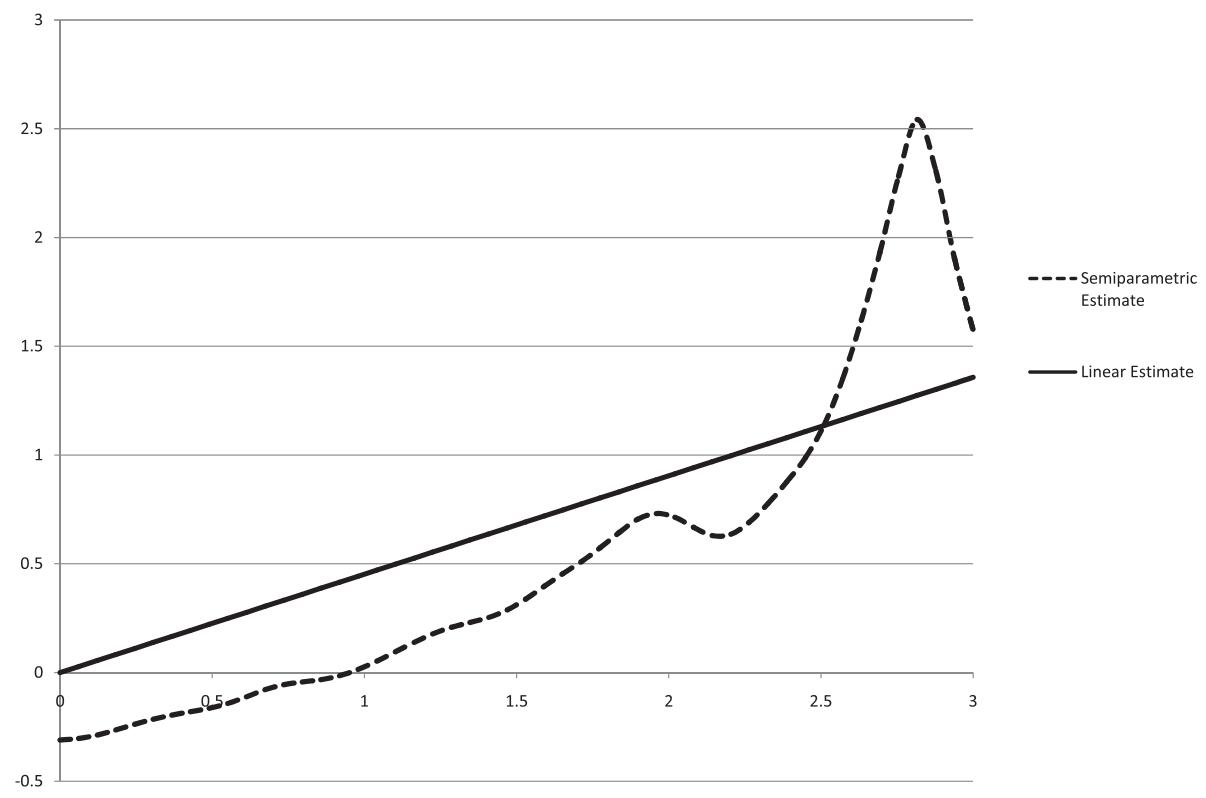

Fig. 6a. Linear and semiparametric estimates of the contribution of loan-to-value to the default decision index, all loans.

probabilities. This strong relative explanatory power is further increased by the fact that current loan-to-value has a wider interquartile range than the affordability index and log income.

A key topic in the existing US research literature is measuring the proportion of mortgage defaulters which are unaffordability (inability to pay) versus strategic defaults. The current loan-to-value ratio is the key variate in a strategic defaulter's decision calculus, whereas loan-to-value has little or no role in a unaffordability-based defaulter's decision calculus. The high explanatory power of current loan-to-value is evidence of strategic decision-making playing at least a partial role (explicitly or subconsciously) by Irish mortgage defaulters. The evidence indicates that
Irish mortgage defaulters in our sample have mixed motives, influenced simultaneously by stressed affordability and strategic motives. Any "pure" strategic defaulters, with no affordability pressure, are more likely to be in the $30 \%$ or so of non-cooperating mortgage defaulters, who do not submit an SFS and are not in our sample.

Note that application loan-to-value and current loanto-value have opposite-signed coefficients, negative and positive respectively, reflecting the importance of property price declines in explaining loan defaults (recall from the discussion above that the difference between these two variables mostly reflects underlying property capital gain or loss). The opposite-signed coefficients on these two variables is indicative of strategic rather than income-driven 


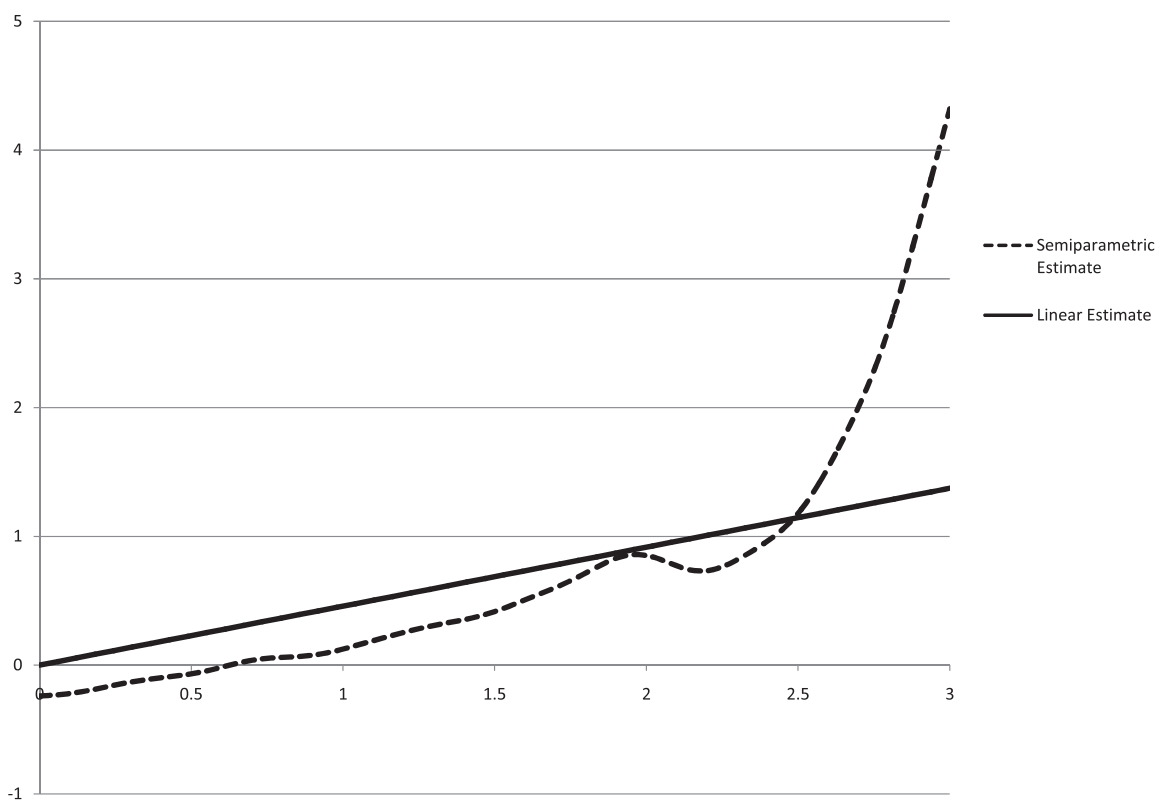

Fig. 6b. Linear and semiparametric estimates of the contribution of loan-to-value to the default decision index, home loans.

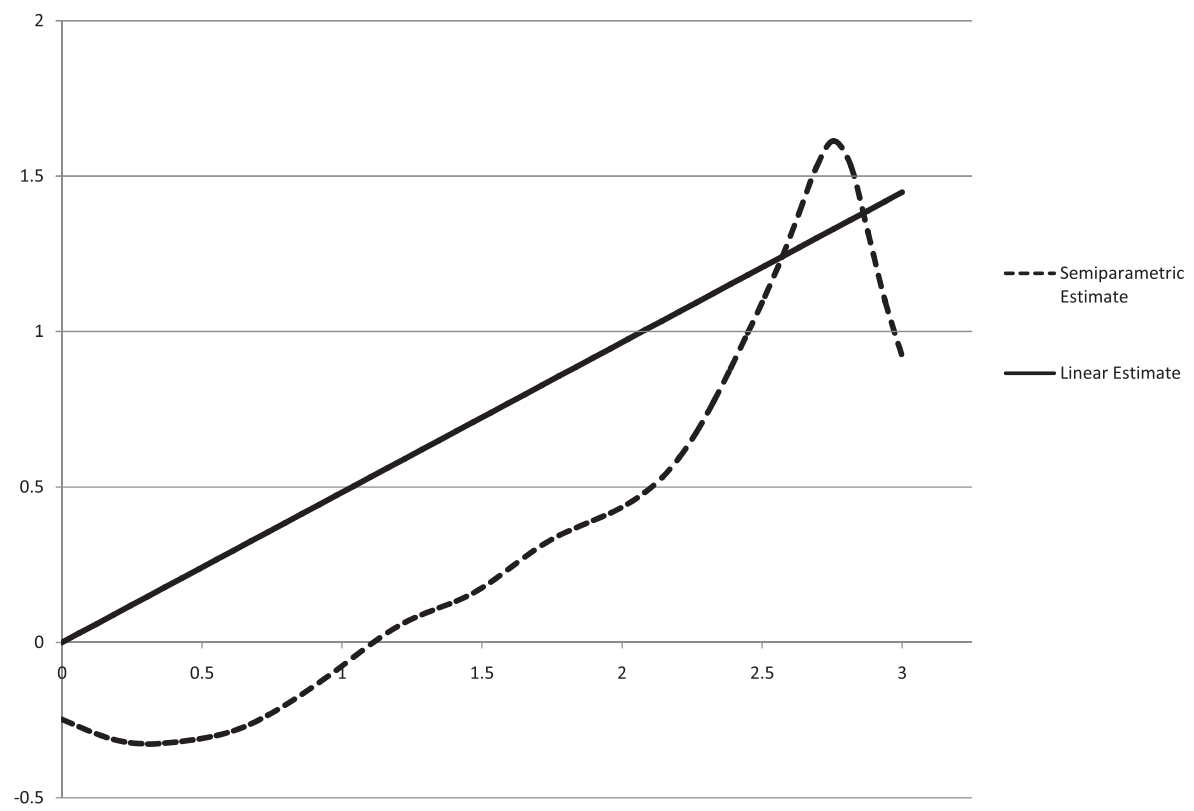

Fig. 6c. Linear and semiparametric estimates of the contribution of loan-to-value to the default decision index, buy-to-let loans.

default behavior. Unaffordability default is not directly impacted by the underlying property's price decline, whereas strategic default depends crucially upon it.

Lastly, we use nonparametric and semiparametric methods to examine potential nonlinearity in the response of default to loan-to-value. We use the Gaussian kernel throughout and set the bandwidth $h$ using Silverman's rule of thumb, $h=\left(\frac{4 \sigma_{d}^{2}}{3 n}\right)^{\frac{5}{5}}$,where $\sigma_{d}^{2}$ is the sample variance of observed defaults and $n$ is the number of observations in the sample or subsample. We estimate over the range
$0<$ LTV $<3$ but note with caution that kernel methods are unreliable in the tails of the data range. The $99 \%$ middle range of the data, leaving $0.5 \%$ in each tail of the sample, is $(.06,2.62)$ for all loans, $(.02,2.28)$ for home loans, and $(.17,3.07)$ for buy-to-let loans. Nonparametric or semiparametric estimates outside this middle range are untrustworthy.

Fig. 4 shows unconditional expected default as a nonparametric function of loan-to-value using kernel-based nonparametric regression; see Eq. (5) in Section 3.2. The 
proportion of loans in default increases as loan-to-value increases for all categories. It is also notable that the rate of increase is greater for higher levels of LTV. Fig. 5 takes the nonparametrically-estimated expected defaults from Fig. 4 and compares them to the conditional expected defaults from the probit model in Table 9; see Eqs. (3) and (5) in Section 3.2. There is evidence for the type of nonlinearity predicted by options theory in Figs. 4 and 5, with the response curves flattening for $\operatorname{LTV}<1$ and curving upward at high LTV. The convex nonlinearity, as reflected in a nonzero linear model bias, seems to start at a loan-to-value ratio of 1.5 for home loans. For buy-to-let mortgages, the convex nonlinearity starts earlier, near a loan-to-value ratio of 1.0. This suggests that own-home occupiers are more reluctant to strategically default than investors with buy-to-let properties. Fig. 6 shows the nonlinear LTV response functions estimated by the partially linear index probit model (see Eq. (7) in Section 3.2). The results are suggestive, but not definitive, regarding a convex nonlinearity in the link between loan-to-value and loan default; see Elul et al. (2010) for related evidence for the US market using different estimation methods (step-wise linearity over intervals in a logit model). The coefficient estimates for the other five variables (for which the linearity assumption is maintained) are shown in the supplementary tables in the unpublished appendix (Connor and Flavin, 2014).

\section{Conclusion}

This paper empirically examines the causes of mortgage default using a unique dataset of troubled Irish mortgages. We differentiate between strategic default, default caused by unaffordability, and dual-trigger default in which strategic and unaffordability effects combine. Irish mortgage data holds considerable interest for studying mortgage default behavior due to the unusual economic and institutional environment of Ireland during our sample period. Following its credit crisis in 2008, Ireland suffered one of the sharpest nationwide property price falls ever recorded: the national residential property price index declined 50.3\% from its 2007 peak to its 2012 trough. In July 2009, the Irish government placed an effective 4-year block on all property repossessions, and 7 months later the Irish Central Bank Ireland implemented very strict regulations on bank communication with delinquent borrowers (these regulations were rescinded in July 2013). During this period, Ireland experienced fast-growing and extremely high mortgage default rates: owner-occupier mortgage defaults grew by $273 \%$ in a 4 year period; in the second quarter of $2013,12.7 \%$ of owner-occupier mortgages had greater than 90 days of arrears, as did $20.4 \%$ of buy-to-let mortgages.

Our empirical analysis supports the dual-trigger model of default: both strategic and unaffordability variates play a significant role in explaining Irish default rates; Irish mortgage borrowers are most likely to default when strategic and unaffordability factors combine.

The consensus view from US-based research is that both unaffordability and strategic motives affect default rates, but unaffordability is the more important motive. In our
Irish sample, the relative strength of these effects is reversed, with the strategic motive a more powerful univariate predictor of default than lack of affordability.

\section{Appendix A. Technical Appendix}

This technical appendix contains background material on the nonparametric regression estimation procedure presented in Section 3.2. First we assume that the default decision index is fully nonparametric:

$v_{i}=f\left(x_{i}\right)+\varepsilon_{i}$

and wish to estimate the univariate nonparametric relationship between $x_{1 i}$ and expected default. Define $g\left(x_{1 i}\right)$ as conditional expected default:

$g\left(x_{1 i}\right)=E\left[d_{i} \mid x_{1 i}\right]=E\left[\left\{f\left(x_{i}\right)+\varepsilon_{i}\right\}^{+} \mid x_{1 i}\right]$

where $\{\cdot\}^{+}$equals one if the argument is positive and otherwise zero. In order to implement nonparametric kernel regression, we assume that $g(\cdot)$ is thrice continuously differentiable. This imposes implicit assumptions on the smoothness of $f(\cdot)$ and on $D$, the multivariate distribution of $x$; we take this assumption as primitive, noting in passing that there are many explicit special cases of $f(\cdot)$ and $D$ which would justify the assumption. Let $\xi_{i}$ denote the mean-zero deviation of realized default from conditional mean default:

$d_{i}=g\left(x_{1 i}\right)+\xi_{i}$

where we assume that the density function of $x_{1 i}$ is thrice continuously differential and that $\xi_{i}$ has uniformly bounded conditional variance $\sigma_{\xi}^{2}\left(x_{1 i}\right)$. Using the Gaussian kernel together with bandwidth $h=\mathrm{cn}^{-\frac{1}{5}}$ to estimate $\widehat{g}\left(x_{1 i}\right)$ by (5), we have by Theorem 2.2 in Li and Racine (2007):

$d \lim \sqrt{n h}\left(\widehat{g}\left(x_{1 i}\right)-g\left(x_{1 i}\right)-b\left(x_{1 i}\right)\right) \sim N\left(0, \frac{\sigma_{\xi}^{2}\left(x_{1 i}\right)}{\operatorname{dens}\left(x_{1 i}\right)}\right)$

where $b\left(x_{1 i}\right)$ is a standard bias correction term; see Li and Racine, page 62 .

In the restricted case, we first estimate $\left(\beta_{0}, \beta\right)$ under the assumption that the multivariate probit holds, and then nonparametrically estimate $\widehat{g}\left(x_{1 i}\right)$ using (6) applied to the predicted default rates from the estimated probit model. We ignore the estimation error in $\left(\widehat{\beta}_{0}, \widehat{\beta}\right)$ since it converges to zero at a faster rate than $\widehat{g}\left(x_{1 i}\right)-g\left(x_{1 i}\right)$. The same Theorem 2.2 from $\mathrm{Li}$ and Racine applies in this case.

\section{Appendix B. Supplementary data}

Supplementary data associated with this article can be found, in the online version, at http://dx.doi.org/10.1016/ j.jhe.2014.12.003.

\section{References}

Asay, M.R., 1978. Rational Mortgage Pricing (Ph.D. diss). University of Southern California, Los Angeles. (Also in Research Paper in Banking and Financial Economics, No. 30, Board of Governors of the Federal Reserve System, 1979.). 
Bellemare, C., Melenberg, B., van Soest, A., 2002. Semi-parametric models for satisfaction with income. Port. Econ. J. 1 (2), 181-203.

Bhutta, N., Dokko, J., Shan, H., 2010. The depth of negative equity and mortgage default decisions. Working paper no. 2010-35. Finance and Economics Discussion Series Divisions of Research \& Statistics and Monetary Affairs Federal Reserve Board, Washington, D.C.

Burke, J., Mihaly, K., 2012. Financial literacy, social perception and strategic default. Working paper no. WR-937. RAND Corporation, Santa Monica, CA.

Cameron, A.C., Trivedi, P.K., 2005. Microeconometrics: Methods and Applications. Cambridge University Press, New York, NY.

Carroll, R.J., Fan, J., Gijbels, I., Wand, M.P., 1997. Generalized partially linear single-index models. J. Am. Stat. Assoc. 92 (438), 477-489.

Connor, G., Flavin, T., 2014. Unpublished appendix: ancillary results and robustness checks on a probit model of Irish mortgage defaults. Working paper N153-14. Department of Economics, Finance \& Accounting, National University of Ireland, Maynooth.

Connor, G., Flavin, T., O'Kelly, B., 2012. The U.S. and Irish credit crises: their distinctive differences and common features. J. Int. Money. Finance 31, 60-79.

Cutts, A.C., Merrill, W.A., 2008. Interventions in mortgage default: policies and practices to prevent home loss and lower costs. Freddie Mac Working paper \#08-01.

Deng, Y., Quigley, J.M., van Order, R., 2000. Mortgage terminations, heterogeneity and the exercise of mortgage options. Econometrica 68 (2), 275-307.

Elmer, P.J., Seelig, S.A., 1999. Insolvency, trigger events, and consumer risk posture in the theory of single-family mortgage default. J. Housing. Res. 10 (1), 1-25.

Elul, R., Souleles, N.S., Chomsisengphet, S., Glennon, D., Hunt, R., 2010. What triggers mortgage default? Am. Econ. Rev. 100 (2), 490-494.
Foote, C., Geraldi, K., Willen, P., 2008. Negative equity and foreclosure: theory and evidence. J. Urban. Econ. 64, 2, 234-24.

Greene, W., 2008. Econometric Analysis. Pearson, London.

Guiso, L., Sapienza, P., Zingales, L., 2009. Moral and social constraints to strategic default on mortgages. Working paper no. 15145. National Bureau of Economic Research.

Li, Q., Racine, J.S., 2007. Nonparametric Econometrics. Princeton University Press, Princeton, N.J. USA.

Lydon, R., McCarthy, Y., 2011. What lies beneath: understanding recent trends in Irish mortgage arrears. Paper delivered at the Central Bank of Ireland conference on the Irish mortgage market in context, Dublin, Ireland.

Mac Coille, C., Lyons, S., McNamara, D., Lang, E., 2013. Ireland.s deteriorating mortgage arrears crisis. Davy research report: Irish economy and the banks.

Matzkin, R.L., 1992. Nonparametric and distribution-free estimation of the binary threshold crossing and the binary choice models. Econometrica 60 (2), 239-270.

Seiler, M., Seiler, V., Lane, M., Harrison, D., 2012. Fear, shame and guilt: economic and behavioral motivations for strategic default. Real Estate Econ. 40 (1), 199-233.

Tirupattur, V., Chang, O., Egan, J., 2010. ABS market insights: understanding strategic defaults. Morgan Stanley Research Note.

Towe, C., Lawley, C., 2010. The contagion effect of neighboring foreclosures on own foreclosures. National Center for Smart Growth, University of Maryland.

Trautmann, S., Vlahu, R., 2011. Strategic loan defaults and coordination: An experimental analysis. Working paper no. 312. Netherlands Central Bank, Research Department.

Wyman, O., 2009. Understanding strategic defaults in mortgages. Experian-Oliver Wyman Market Intelligence Report 2009 Topical Report Series. 